\title{
The VENETS of NOBLEWOMEN in the GRAND DUCHY of LITHUANIA
}

\author{
Irena VALIKONYTE \\ Vilnius University
}

Historians have long recognized in that in the Grand Duchy of Lithuania land inheritance rights of men and women were different. In general, the legal position of privileged-estate women with respect to property was quite solid. Nevertheless, women's property rights were least restricted only when they became widows and, temporarily at least - until their children attained their majority, could manage the whole or part of their deceased husband's estate. In the First and Second Lithuanian Statutes over half of the articles of the 'female Section" (and in the Third Statute - a half of the articles) dealt with the particular property rights of the widow, and not of the betrothed or married woman. The exceptional status of the widow was also evident to contemporary commentators. In the mid-sixteenth century, the Grand Duke's secretary Michalo Lituanus, who criticised many negative customs and phenomena of the time in his treatise De moribus Tartarorum, Lituanorum et Moschorum, was dissatisfied with unlimited women's rights and in particular with the status of the land-owning widows. ${ }^{1}$ That such an opinion was prevalent in sixteenth-century society is attested by the tendency to limit those rights, and that is evident both in the wording of the Statutes and in the petitions of the gentry presented at the Diets (of 1551, 1554) to limit the rights of the widows as guardians of their daughters. ${ }^{2}$

Therefore it is no accident that research hers of family relationship in the Grand Duchy have been interested in the status of the widow, and special attention has been given to the dower (dotalicium, veno) as an institution - its genesis, development and legal regulation. ${ }^{3}$ However, the venets (crinile, crinale, venec), which in certain instances

'M. Lietuvis. Apie totoriu, lietuviu ir maskvenu papročius. Vilnius, 1966, 28, 55.

${ }^{2}$ I. Valikonytè. Ar Lietuvos Didžiojoje Kunigaikštystèje XVI a. moteris buvo pilietė? Lietuvos istorijos studijos. 2. Vilnius, 1994, 66-67.

${ }^{3}$ L. Veržbavičius. Scnoji šcimos tcisc. Teisè. No. 19, Kaunas, 1931, 26-44; J. Bardach. Studia z ustroju i prawa Wielkiego Księstwa Litewskiego XIV-XVII w. Warsan, 1970, 185-187; S. Lazutka, I. Valikonytć. Privilegijuoto luomo moters (motinos, žmonos, dukters, sesers) turtine padètis pagal I Lietuvos Statutą. Aukštuju mokyklu mokslo darbai. Istorija. XVI(2). Vilnius, 1976, 74-102; V. Andriulis. Tcisinis šcimos turtinių santykių reguliavimas Lictuvojc XIII-XVI a. Teisiniu institutu raida Lietuvoje XIV-XIX $a$. Vilnius, 1981, 79-100. 
secured the property status of the undowered widow, has been investigated less comprehensively. In special studies devoted to the property status of the dowerless widow, Vladimir Spasovich and I. I. Skitskii, limit their investigations mainly to the analysis and interpretation of legal documents (mostly sections of the Lithuanian Statute). ${ }^{4}$ The same can be said about the Lithuanian legal historian Vytautas Andriulis's work on the regulation of family property relations in the Grand Duchy. ${ }^{5}$ Undoubtedly, the Lithuanian Statute is the principal source shedding light both on the status of the widow and the concept of the venets and the conditions of its assignment. However, in order to establish the origin and the development of this institution and especially the real chances of the widow to exercise that right, it is necessary to resort to other sources, in particular to the Lithuanian Metrica and to district (povet) court books of the late sixteenth century. Analysis of these sources, which reflect the dowerless widow's property rights, reveals a paradoxical situation, which developed in the Grand Duchy in the sixteenth century.

The head of the gentry family and the owner of its property was a husband, but a wife, having brought her dowry to the new family, also had certain protective rights in respect to her property, and these were guaranteed by customary law, and later - by special legislation: the Regulations of the Council of Lords (1509), appropriate paragraphs of Section Four of the First Lithuanian Statute of 1529 and of Section Five of the Second (1566) and Third (1588) Statutes. Thus, already in the first half of the sixteenth century the laws of the Grand Duchy stipulated that a husband, having evaluated his wife's dowry, had to ensure it at its double value by assigning her some estates as her dower. Although Paragraph 8 of Section Four of the First Lithuanian Statute obliged the father of the bride to ensure that his son-in-law did not 'forget' to assign her the dower, the law also protected the interests of a widow whose husband, for some reasons, before his death had not willed her the dower. In such a case she was entitled to part of the family property. In any way, such a widow had rights to part of her deceased husband's estates for life. If she was childless, she inherited a third; if she had sons, she was entitled to a part equal to that of each of her sons." The Second and Third Statutes contained that stipulation, too. ${ }^{7}$ However, the law treated the dowerless widow's property

${ }^{4} \mathrm{~B}$. Спасович. Об отношениях супругов по имуществу по древнему польскому празу. Сочинения. Т. Ш. С.-Петербург, 1890, 147-160; И. И. Скитский. Незенованные вдозы по Литовскому Статуту и по толкованию Сената. Журнал министерства Юстицин. 1907, No 7,c. 19-64, No. 8, с. 141187.

${ }^{5} \mathrm{~V}$. Andriulis. Tcisinis šcimos..., 98-99.

"Pirmasis Lietuves Statutas, t. II, d. I: Tekstai senaja baltarusų, lotynų ir scnaja lenkụ kalbomis. Vilnius, 1991, 122, 124, 126.

${ }^{7}$ Statut Litcwski drugicj redakcyi (1566). Archiwum Komisyi prawniczej. T. 7, Kraków, 1900, 130, 131; J. Lappo. 1588 metu Lietuvos Statutas. T. II (Tckstas). Kaunas, 1938, 285. 
rights differently in the event of her remarriage. It was here that the institution of the venets came to the fore.

In their commentary-cum-glossary, the editors of the Minsk edition of the First Statute (to be more precise - Konstantinas Jablonskis, as is evident from his unpublished manuscripts ${ }^{8}$ ) define the venets as a sum to be paid to "a gentry widow, leaving her deceased husband's estate, by its heirs, if, being her first husband he had not willed her a dower". This definition reveals the concept, but it does not say anything about its origin and development in the Grand Duchy. The comparison of the respective articles in the three Statutes shows that the conditions of the assignment and the size of the venets varied during the sixteenth century. The First Statute repeatedly stresses that the children or relatives are not obliged to give a venets to a dowerless widow on her remarriage (Article 3, 4 and 8 of Section Four). ${ }^{10}$ However, the Second Statute contains a opposite norm, according to which the children or other heirs of the property of a dead boyar had to pay the dowerless widow a venets of thirty kopas of groasz (Article 1, Section Five). If the value of the estate did not come up to that sum, the widow had a right to use one fourth of the estate for life." Statute retained that norm, but it restricted the rights of the poorest widows, permitting the heirs of the dead man's property to ransom from the widow one fourth of the estate as her venets by paying her only a half of its value (Article 1 , Section Five). ${ }^{12}$ In general, the Second and Third Statutes improved the remarrying dowerless widow's property ownership. Nevertheless, these changes in the venets norm lead to the question: if the First Statute made no provision at all for the assignment of a venets why was it necessary to introduce articles forbidding a widow to get it? Does that mean that prior to the adoption of the First Statute the venets assignment to noblewomen had been practised and the inclusion of that norm into the Second Statute was merely a return to the old custom or a previously valid norm? The answer to this question is difficult because up to the present only one mention of the venets in non-legal documents has been noted. And, most importantly, it is found in a document, produced in 1495, i.e., much earlier before the compilation and adoption of the First Statute. There is one more paradox: in the First and Second Statutes (Articles 3, 4 and 8 of Section Four and Articles 1, 5 and 9 of Section Five respectively) the term venets is used three times in each code, while in the Third Statute it is already used four times (Articles 1 (twice), 6

${ }^{8} \mathrm{MARB}$, f. $256-333,1.1$

"Статут Великого княжества Литовского 1529 года. Минск, 1960, 226.

"Pirmasis Lietuvos Statutas, 124, 130; see also The Lithuanian Statute of 1529. Translated and cditcd with an introduction and commentary by Karl von Locwe. Leiden, 1976,43 .

${ }^{11}$ Statut Litewski drugiej redakcyi, 130

12J. Lappo. 1588. 285. 
and 10): that would somehow indicate an increase in the use of this institution of women's property rights. In court practice this term is virtually non-existent. In a situation like this it is particularly important to establish when and how the term venets and its definition originated and gained currency in the Grand Duchy.

In the Lithuanian state the assignment of the dower found its juridical expression in the Horodle Privilege of 1413. Special decrees, indicating "in what way everybody in his estate had to assign a dower to his wife" were adopted by the Grand Duke and the Council of Lords only in 1509. Again, these regulations dealt with the inheritance rights only of those widows that were assigned dowers by their husbands; and no mention was made of the dowerless widows. ${ }^{13}$ As the regulations of 1509 also lacked any imperative tone ("... if someone wishes (sic) to assign a dower to his wife..."), it is no wonder that property lawsuits involving widows and other heirs, were frequent. This supposition is supported by the contents of the Lithuanian Metrica for both the latefifteenth - and of the first decades of the sixteenth century. In 1495 Grand Duke Alexander himself had to investigate a lawsuit of that kind, dealing with the property of a certain Andrei after his death. His brother alleged that the deceased had willed him a third of his estate, and two thirds made up the dower of his wife. The widow married again and her second husband Boris claimed that he had obtained permission from Grand Duke Casimir to marry the widow "with all the estates" of the deceased Andrei. However, Boris could not produce any document attesting such a fact, as, in the witnesses' words, he himself destroyed it in the presence of the scribe. The ruler, reasoning that it would "not be right and proper" for him to deliver judgement on the validity of the widow's dower without having seen the written assignment of the deceased, made a decision to award to her "venets shliakhetskii, i.e., thirty grivny. ${ }^{14}$ Here some points deserve special attention. Firstly, the venets is assigned to a widow, who married again. Secondly, though the formulation of the judgement does not explicitly say that the judges treated the widow as dowerless, it could be surmised that the failure to produce the document confirming the assignment of the dower was considered equal to the absence of the dower. Consequently, it could be maintained that the decision, adopted in the late-fifteenth century corresponded to the norm legitimized only in the Second Statute, i. e. on remarriage, a dowerless widow, leaves her part of the deceased husband's estate to the other heirs and receives,

${ }_{13}^{13}$ Русская историческая библиотека (РИБ). Т. ХХ: Литовская Метрика. Т. I. Петербург, 1903. No 54, с. 596-597.

14“.... ижь то ест|ъ| речь неслушная,не видевшы записовъ, всказызати вено Борисовой жоне на его поведанье, ... жоне Борисовой присудили есмо венецъ шляхецкий тридцать гризенъ ...РИБ. Т. XXVII: Литовкая Метрика. Отдел первый. Ч. І. Книги Записей. С.-Петербург, 1910. № 100, с. 620-621. 
a compensation from them, namely - the venets. Its size varied: in 1495 it was 30 grivny, i.e., 24 kopas of groasz, and in the second half of the sixteenth century it increased to 30 kopas. Thirdly, although the decision was taken by the Grand Duke in consultation with the Council of Lords, the act does not contain any indication of the basis of the judgement, i.e., no reference is made to either custom or "law".

In this respect, an act of 1508, found in the eighth Book of Records of the Lithuanian Metrica is very important. It deals with the case of the Smolensk boyar in Fedkovaia Ragozicha, whom her brothers-in-law had driven out of her deceased husband's estates. Grand Duke Sigismund the Old, investigated the complaint and took a decision, enabling the widow to remain for life "as a widow" in her dead husband's estates and obliged her brothers-in-law to pay her a venets "according to the custom of land law", should she remarry. ${ }^{15}$

There are only two known acts, indicating that prior to the adoption of the First Statute there existed in the GDL a "law custom" of assigning a venets to a remarried dowerless widow. True, there are also some other documents of the same period, which referindirectly to the venets, without explicitly defining it. Thus, in 1518 the land marshal Jan Radivil had to pass a judgement in the case of Hanna Bogushovaia, who produced at the court her deceased husband's will which was considered invalid by a relative of her husband, because the sum of the money willed to the widow, surpassed the value of his estates. Radivil applied for advice to the Council of Lords which recommended "nullifying" the will as it had been made "in an unsuitable way". The court affirmed the widow's right to stay for life in the estates of her deceased husband, and, with an eye to the future, ruled that in that should she remarry the kin would be able to regain the estates after having "paid her the dower of 30 grivny according to land law". ${ }^{16}$ It is worth noting that after four years (in 1522), when the same widow was sued for the same estates by another relative (a brother of the deceased), she produced the previous judgement of Jan Radivil. This time the case was investigated by Grand Duke Sigismund the Old, who confirmed the validity of the previous sentence and once again indicated that if the widow remarried, the heirs of the estates would have to pay her a 30 grivny dower "according to land law". ${ }^{17}$ The situation in these two cases is almost analogous to the case of 1495. In the first instance, however, the assignment of the dower was

15““А естьли похочетъ она замужъ поити, и они мают еи венецъ ее заплатити подълугъ обычая прав земъслихъ.” Lietuvos Metrika. Knyga No. 8 (1499-1514). Užrašymų knyga 8, red. A. Baliulis, R. Firkovičius, D. Antanavičius. Vilnius, 1995, No. 414, p. 312 .

16 “.. тоть маеть ей вена, подле права земского, отложити тридцать гривенъ, а именъя къ своей руце взяти." РИБ. Т. ХХ, No 19(1), с. 1226.

17“... естли бы замужь пошла, ино тогды близкии мають вена отложити тридцать гривенъ, подле права земского ... ." РИБ, Т. ХХ, № 364, с. 1083. 
not proven, and in the second it was considered invalid. It could be surmised that in the latter case the court considered that the widow had been assigned a dower (because actually it had been assigned, though not according to the rules), and the property belonging to the woman was called 'dower' and not venets. Nevertheless it remains unclear why the judges foresaw the payment of 30 grivny (i.e. the sum equal to the venets according to the judgement of 1495) to the widow in case of her second marriage.

A similar case had been investigated by Jan Radivil before - in 1517. Three brothers Ianovich sued their stepmother who, on remarriage, did not give them back their patrimonial estate. In her turn, the defendant Alzhbeta accused her stepsons of refusing to pay her the dower "according to the custom of land law". ${ }^{18}$ The stepsons, who had already accused their stepmother in 1516 for allegedly illegally possessing a fourth part of the estate as a 30 grivny dower, ${ }^{19}$ a year later "forgot" about it and told the judge that they were not aware of their duty to pay their stepmother a dower and that they were ready to pay her as much as the court would consider necessary (sic). A dower undoubtedly had not been assigned to the widow (that is why she owned one fourth of the estate), her share being equal to that of each of her three stepsons. The judge made a judgement that after remarriage the woman was entitled to a dower of 30 grivny "according to the custom and the decrees of the ruler". ${ }^{20}$ Although in that act the definition of the dower was again used, it could be stated that the institution of the venets was meant, all the more so, as it was no mere chance that the widow herself made a point about her being a virgin at the time of her first marriage, i.e., the father of her stepsons was her first husband. ${ }^{21}$ The analysis of the extant LM acts of the early sixteenth century shows that at that time the assignment of the dower to remarried dowerless widows as a compensation in the form of 30 grivny was widely practiced and mostly was referred to as a dower rather than venets. It is noteworthy that such sentences of the law courts were based on "land regulations", "decrees of the ruler" and even "the custom of land law." To tell the truth, a sort of exception was the judgement, made by the same Jan Radivil in the investigation a dower of a property dispute between the widow Alzhbeta Iushkovskaia and her stepson Mikolai Iushkovich. It is difficult to say why Radivil, after hearing the widow's justification for not leaving the estate of her deceased husband because her stepson had not given her a dower, decided to apply to the ruler

${ }^{18}$ Ibid. No $370(1)$, c. $498-499$.

I"Ibid. No. 311, c. 416.

2юк И мы сказали имъ заплатити той мачесе ихъ Ольжбете вена тридцать гривенъ, какъ естъ обычай и устава господарьская". Ibid. No 370(1), с. 499.

21 ‘... муж мой небожчикъ Янъ, ... понялъ мене панною за себе ..." Ibid., 499. 
for advice, ralsthew than resolving the case hinself. The dispute was resolved by Sigismund as follows: if the woman had not married the second time, she could have lived as a widow for life in her deceased husband's estate: However, because she had no dower from him and she remarried, "she cannot be paid a dower; neither can she stay in the same estate". ${ }^{22}$ Thus for unknown reasons this time the Grand Duke did not assign the woman any compensation on this occasion. However attention should be paid to the fact that Alzhbeta had no children from the stepsons' father - a circumstance particularly stressed by Mikolai. Meanwhile, the woman rejected the accusations of her stepson that the had squandered the property of the deceased, and justified herself on grounds of having given one serf maid to her daughter. It is quite believable that that daughter had been born during her previous marriage, and the deceased had not been her first husband. In this likely concurrence of circumstances she was in no way entitled to compensation (venets).

The material, presented above, leads to a conclusion that in the pre-Statute period the venets existed in a general way as an institution, and than in the practice of the courts it was usually called 'dower', i.e., even the property of the dowerless widows was referred to as 'dower'. ${ }^{23}$

In their works related to the institutionalization of the venets in the Grand Duchy, nearly all researchers have considered that as an institution it was taken over directly from Polish law. ${ }^{24}$ Such a viewpoint can be supported by several arguments: the size of the venets, its expression in grivny, and lastly, the very name of the institution. However, the same sources also indicate that it would not be safe to speak about a simple direct adoption of the institution. The origin and institutionalization of the venets in the Grand Duchy was rather complicated and particular. This was quite natural, since in the contemporary Polish Kingdom that institution had still not taken definite uniform shape. Although the custom to pay the dowerless widow a 30 grivny venets had been known in Little Poland in the fifteenth century, ${ }^{25}$ it became a juridical norm only in King Alexander's Statute of $1505 .{ }^{26}$

22 “... естли бы она за иншого мужа не пошла, мела бы, какъ то вдова, на именьи мужа своего до живота своего мешкати; а коли вжо за иншого мужа пошла, а муж ее Юхно вена ей въ тастоменте на именьи своемъ не отписалъ, тогды ей вена не маетъ плачоно быти; на том именьи далей того не маетъ она мешкати". РИБ. Т. ХХ, No 252(1), с. 336.

${ }^{23}$ Morc extcnsively sec I. Valikonytc். Našlés vainikiné Lietuvos Didžiojoje Kunigaikštystċjc XVI a. : norma ir realybé 1566 metu Antrasis Lietuvos Statutas. Resp. moksl. konferencijos... medžiaga. Vilnius, 1993, 85-86.

${ }^{24}$ В. Спасович. Об отнашениях., 159-160; Статут Великого княжества Лттовского 1529 года, 226.

${ }^{25}$ B. Lesiński. Stanowisko kobiety w polskim prawie ziemskim do potowy XV wieku. Wrocław, 1956, 121.

${ }^{26}$ Volumina Legum. T. I. Pctersburg, 1859, 148. 
However, in the corresponding article, institutionalizing Kraków land custom, the assignment of a venets of as to a dowerless widow was not associated with her new marriage, as it was the case in Lithuania even though such a decision had been taken by the same Alexander in 1495. True, in Mazovia the assignment of a venets to dowerless widows on remarriage was made law in 1540, its size was twice as small (15 kopas grosh) $)^{27}$ as stipulated by the Second Lithuanian Statute.

Historians have defined the venets as compensation for lost virginity. In actual fact, both in Poland and in the GDL only widows after their first marriage had rights to a venets. ${ }^{28}$ Juliusz Bardach has drawn attention to an important issue; namely, in Poland the size of the venets and the fine for rape were the same, ${ }^{29}$ which, in its turn, again accentuates the moral significance of the institution of venets. Although in Lithuania the compensation for violating the chastity of noblewoman differed from the venets, the venets norm, indicated in the Lithuanian Statute, was conceived as compensation for maidenhood. That was also attested by the translation of the Second Statute into Latin, where, in the corresponding articles of Section Five, the term venets was rendered as pro crinili or virginitatis precium..$^{30}$

Nevertheless, even in the mid-sixteenth century the definition of venets did not easily make its way into the practice of the courts of law in the GDL. The fact that no acts relating to the assignment of venets have been found in the period of the First Statute can be accounted for by the absence of that institution in the Statute itself: "If [she] marries, then this share must go to the children, and the children are not obligated to give her a venets, as [is done] when [the mother] does not have a dower from her husband". ${ }^{31}$ Therefore it is understandable that the parents, before giving their daughter in marriage, first demanded that their son-in-law first provide a dower, as was decreed in Section Four, Article 8. The reasons and intentions of the Statute compilers for denying the dowerless remarrying widows the right to a venets are unknown. It was quite evident that that flagrant injustice and numerous complaints of the widows about their material losses, i.e., the actual loss of their dowry, brought to the husband's manor, without any compensation, made the legislators make a radical change in the law. No doubt, even after the introduction (more precisely, the re-introduction) of the venets into the Second Statute the bride's relatives were concerned over the assignment of the dower. Therefo-

${ }_{27}$ B. Lesiński. Stanowisko..., 120-121; B. Спасович. Об отношениях., 143.

${ }^{28}$ B. Lesiński. Stanowisko..., 120-121; Statut Litewski drugiej redakcyi. P. 134, (V. 5); J. Lappo. 1588, 292 (V. 10).

29) J. Bardach. Historia państwa i prawa Polski. I: do połowy XV wieku. Warsaw, 1973, 495.

${ }^{311}$ Statut Litewski drugiej redakcyi, 130, 134, 136.

${ }^{31}$ The Lithuanian Statute of 1529, 43. 
re, the number of dowerless widows was small, and lawsuits concerning assignment of a venets were rare. However, numerous documents of the second half of the sixteenth century indicate that dowerless widows required from the heirs of the estate a venets, but for unaccounted reasons used the term 'dower'. Due to the absence of corresponding materials it is difficult to explain the 'unwillingness' of the public and its stubborn 'resistance' to identify the property of the dowerless widows with their dower. ${ }^{32}$

Two acts in the late-sixteenth-century land court books of Žemaitija and Upyte enable one to maintain that the term venets was used, albeit rarely. In 1585 in the land court of Upyte a landowner of that povet, Dorota, sued her drowned husband Ian Aleksandrovich's sons Stanislav and Ventslav, who, according to her account, had driven her, 'being a widow,' out of her dead husband's estate by force and taken the whole property for themselves. ${ }^{33}$ The defendants said that they had not only not hurt her, burt also that they were even unaware that Dorota had lived with their father as his wife - she also "could have passed for some cook." It was only when a special document about the marriage of Dorota and Ian Alexandrovich, signed by the Pasvalys parish priest, was produced at the court, did the stepsons acknowledge Dorota as their stepmother and let her live in her dead husband's estate. Her solicitor Stanislav Devchepolskii, however, evidently endeavouring to protect the widow's rights in the future, as the minutes of the court proceedings show, quoted Article 1 of Section Five of the Second Statute, related to the assignment of a venets. The judges, basing their sentence on that article, permitted the widow to have a part of the estate, equal to that of the sons of Ian Aleksandrovich until her second marriage. "In case of her marriage Ian Aleksandrovich's sons would have to pay Dorota a venets of 30 kopas of Lithuanian groasz in accordance whith the Statute". ${ }^{34}$ Thus, in this case the judges were guided by a legal regulation of the Lithuanian Statute. There are also indications that the widows themselves were well versed in their rights and the ways of using them. In the same year (1585) Hanna Tsibinskaia, a landowner from Samogitia, applied to the court of law with a request to introduce into the povet books her "assignment document", confirmed by her seal and those of the witnesses in Raseiniai on 18 June. ${ }^{35}$ The document deals with a situation very typical of the second half of the sixteenth century: the woman of her own free will "transfers in perpetuity" to her second husband Stanislav Tsibinskii,

${ }^{32}$ I. Valikonytc். Našlès vainikinè..., 87-88.

${ }^{33}$ VUBR, F. 7, Upytès žemès aktai, no. 19, fo. 318-323.

з4“А если бы замуж пошла, тогды сынове Яна Алексанъдровича мают(ь) и повинни будут(ь) той Дороте водлугъ Статуту венца трыдцат(ь) гр(о)шей личбы литовское заплатити."Ibid., 1. 323.

${ }^{35}$ VUBR. Žemaičių žemess aktai / 1585, f. 7, no. 40, 1. 151-154. 
i.e., makes him a gift of 30 kopas of groasz and some other property, expressing her gratitude for his support to her and her children in overcoming economic hardships after the death of her first husband Grigorii Tomaitis. However, such cases were when a woman documentally 'took' for herself the venets legally belonging to her - 30 kopas of groats, which, as she said in her letter, "must belong to me according to state law and the land statute for my virgin venets after the death of my first husband Tomaitis". ${ }^{36}$ True, in her verbal statement in the presence of the judges Hanna mentioned that she had given that venets to her second husband, after having obtained a permission of the sons (i.e., the heirs of the estate) of her first husband and in written form authorized Tsibinskii to manage the estate of the deceased until her sons paid him the indicated sum. It is interesting that in her official letter Hanna used a term, not recorded in the Statute - venets panenskii (a virgin's venets). The Statute (section Five, Article 1) and the above-mentioned act of the Upyte lawcourt laid greater emphasis on the social aspect - the venets assignment to a dowerless widow as a gentry woman (jako shliakhtiantse). It is also worth noting that Grand Duke Alexander used the term venets shliakhetskii. Nevertheless Hanna's interpretation of the concept did not violate the spirit of the stipulation of the Second Statute, because Article 5 of Section Five stressed that a venets could be assigned to a dowerless woman who had married "not being a widow", i.e., she married being a virgin. Thus Hanna accentuated all the moral reasons for her obtaining a venets.

On the basis of the documents, discovered thus far, the institution of venets and its definition could be said to have become not only a juridical norm but also a reality for the gentry of the second half of the sixteenth century. The comparatively rare usage of the term could be accounted for by the proximity of the origin and the contents of veno and venets - venets was the 'same' veno, only assigned not by the husband, but by state law. Numerous sixteenth-century sources show that in everyday life, even in various documents drawn up by the gentry (wills, donation acts, dower assignments, etc.) there was no any established boundary between this legal institution and its corresponding commonplace concept, and terms relating to women's property were used rather imprecisely. ${ }^{37}$ For example, in the same year as the above-mentioned Hanna from Samogitia "assigned" a venets to herself, a gentry woman of the Upyte povet Hanna Petrovaia required from her sons by hereditary law a dower, belonging to her and clearly based her request on the legal norm dealing with the venets in Section Five, Article 1 of the Statute: "30 kopas dower or ... a quarter of culti-

36.... которая трыдцат(ь) коп грошей водлугъ права посполитого и Статуту земског(о) мне за венец мой паненский по первшом мужу моем Тумайтю мети приналежит(ь)." VURB F7, No 40, 1. 152.

${ }^{37}$ S. Lazutka, I. Valikonytc். Ibid., 84-93. 
vated land to be apportioned according to the Statute". ${ }^{38}$ And the woman was nearly right, because the circumstances under which the widow could get her venets showed that it was a kind of compensation not only for her virginity, but also for the dower, not assigned to her by her husband. In other words, the venets was a dower for the dowerless widow. Obviously taking that into account, some widows required from the heirs of their deceased husbands' estates a dower rather than a venets. On the other hand, the dower had been institutionalized in the GDL much earlier and had become commonplace in the everyday life of the gentry. That could also have been a reason why even in the late sixteenth century the property of the dowerless widow was mostly identified with the dower, despite the fact that the Lithuanian Statute clearly differentiated between the two institutions and their definitions.

38“... яко матце ихъ рожоной, правомъ прирожонымъ, то естъ вена копъ тридцать, або теж кгрунту земленого выделили водлугь статуту четвертую часть ...". Акты, издаваемые Виленской археографической комиссией. Т. 26. Вильна, 1899, No 50 , c. 31-32. 